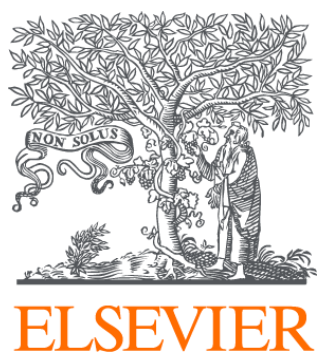

Since January 2020 Elsevier has created a COVID-19 resource centre with free information in English and Mandarin on the novel coronavirus COVID-

19. The COVID-19 resource centre is hosted on Elsevier Connect, the company's public news and information website.

Elsevier hereby grants permission to make all its COVID-19-related research that is available on the COVID-19 resource centre - including this research content - immediately available in PubMed Central and other publicly funded repositories, such as the WHO COVID database with rights for unrestricted research re-use and analyses in any form or by any means with acknowledgement of the original source. These permissions are granted for free by Elsevier for as long as the COVID-19 resource centre remains active. 


\title{
Human B cell memory
}

\author{
Antonio Lanzavecchia and Federica Sallusto
}

\begin{abstract}
Following an immune response two types of differentiated $B$ cells persist in the memory pool: plasma cells, which confer immediate protection by the secretion of specific antibodies; and memory B cells, which confer rapid and enhanced response to secondary challenge. We will review recent advances in understanding the heterogeneity, dynamics, and persistence of human memory B cells and plasma cells as well as new methods to isolate human monoclonal antibodies. These findings offer new insights into the human B cell response, which are relevant for vaccination and therapeutic intervention.
\end{abstract}

\author{
Address \\ Institute for Research in Biomedicine, Via Vincenzo Vela 6, CH-6500 \\ Bellinzona, Switzerland \\ Corresponding author: Lanzavecchia, Antonio \\ (lanzavecchia@irb.unisi.ch) \\ Current Opinion in Immunology 2009, 21:298-304 \\ This review comes from a themed issue on \\ Lymphocyte activation and effector functions \\ Edited by Michael McHeyzer-Williams and Michel Nussenzweig \\ Available online 6th June 2009 \\ 0952-7915/\$ - see front matter \\ Published by Elsevier Ltd.
}

DOI 10.1016/j.coi.2009.05.019

\section{Longevity of B cell memory}

It is well established that in the course of a $\mathrm{T}$ celldependent $B$ cell response naïve $B$ cells proliferate and differentiate to memory $\mathrm{B}$ cells and long-lived plasma cells $\left[1,2^{\bullet}, 3\right]$. Using highly purified human naïve B cells it was shown that optimal expansion, differentiation, and class switch requires, in addition to BCR triggering and T cell help, a third signal that can be delivered by TLR agonists or by cytokines produced by activated dendritic cells [4]. These findings are consistent with mouse experiments that addressed the requirements for TLR expression on $\mathrm{B}$ cells in certain types of $\mathrm{T}$-dependent responses $[5,6]$.

Polysaccharides behave as $\mathrm{T}$ cell-independent antigens and activate B cells by crosslinking the BCR. Polysaccharide vaccines have been available for decades, but provide only short-term protection and are thought to be unable to generate B cell memory. It has been shown that vaccination with polysaccharides leads eventually to the exhaustion of antigen-specific B cells [7]. By contrast, protein-polysaccharide conjugate vaccines elicit T-dependent responses and long lasting memory, at least in adults [8].

The concept that memory $\mathrm{B}$ cells are derived only from $\mathrm{T}$ cell-dependent response has been recently challenged by the finding that in mice $\mathrm{T}$ cell-independent type II responses to bacterial polysaccharides lead to the expansion of memory $\mathrm{B}$ cells with a distinct CD2 $1^{\text {lo }} \mathrm{CD} 23^{\text {lo }}$ phenotype [9]. The activation of these memory $\mathrm{B}$ cells is strongly suppressed by $\operatorname{IgG}$ antibodies, a finding that may explain the hyper-IgM syndrome in patients lacking CD40L or AID [10,11].

Longevity remains the key aspect of immunological memory and applies to both plasma cells and memory $B$ cells. In a recent longitudinal study it was shown that antiviral serum antibodies induced by infection or vaccination with live viruses are stable with half-lives ranging from 50 to 200 years, while antibodies induced by protein vaccines have half-lives of $10-20$ years [12 ${ }^{\bullet}$ ]. The longevity of plasma cells is determined by extrinsic factors that are collectively defined as 'survival niches' [13]. In contrast to adult vaccination, vaccination in early childhood does not lead to sustained serum antibody levels [8]. In a mouse model this failure has been attributed to a defective capacity of bone marrow stromal cells to produce APRIL, which is required for the maintenance of long-lived plasma cells [14]. A better definition of the mechanisms that control plasma cell survival will be required in order to improve vaccination in early life.

In humans all memory $B$ cells recirculate through the blood, but their main reservoir is represented by lymphoid tissues, such as the bone marrow and the spleen $[15,16]$. Their survival requirements remain to be defined. Mouse studies indicate that BlyS is required for the maintenance of naïve $B$ cells and APRIL for the maintenance of plasma cells, while both ligands appear to be dispensable for the survival of memory $\mathrm{B}$ cells $[17,18]$. Conditional deletion of the PLC- $\gamma 2$ gene depletes memory $\mathrm{B}$ cells and abrogates secondary antibody responses [19].

There is evidence that under steady-state conditions human memory B cells are slowly dividing [20,21] suggesting that the memory $B$ cell pool may be maintained through homeostatic proliferation as it is the case for memory $\mathrm{T}$ cells. This view is supported by the observation that memory $\mathrm{B}$ cells are highly responsive to polyclonal stimuli [22]. At present a B 'memory stem 
cell' has not been identified and remains a matter of speculation.

The lack of functional SAP leads in both humans and mice to a B cell deficiency characterized by defective germinal center formation and lack of B cell memory $[23,24]$. Using two-photon intravital imaging it was shown that SAP deficiency selectively impairs the ability of CD4+ T cells to stably interact with cognate B cells, thus preventing the delivery of effective $T$ cell help required for germinal center and memory formation $\left[25^{\circ}\right]$.

\section{Human B cell and plasma cell subsets}

Subsets of memory B cells and plasma cells can be defined on the basis of the expression of surface markers. Although CD27 has been widely used as a marker for memory B cells [26], there is a substantial fraction of bona fide memory B cells that lack CD27 expression [20]. These CD27-memory B cells have been mistakenly taken as naïve cells, a fact that has generated some confusion in the field. The ABCB1 transporter is expressed exclusively on human mature naive $B$ cells but not on immature, activated or memory B cells, including those lacking CD27 [20]. In humans constitutive TLR expression is a characteristic of memory but not of naïve $B$ cells, thus explaining the capacity of the former to readily respond to TLR agonists in the absence of BCR stimulation [27].

FCRL4 is an inhibitory receptor expressed on a unique population of human memory B cells, which resides in epithelial tissues and is characterized by distinctive transcript and protein profiles [28]. Recently a similar population of tissue-like memory B cells (FCRL4+, CD20 ${ }^{\text {lo }}$, CD27- ${ }^{-}$, and $\mathrm{CD} 21^{\mathrm{lo}}$ ) has been identified in the blood of HIV-viremic individuals $\left[2^{\circ}\right]$. These cells have an 'exhausted' phenotype since they express multiple inhibitory receptors and proliferate poorly when stimulated in vitro. Strikingly, HIV-specific responses were enriched in these exhausted B cells, whereas influenzaspecific responses were enriched in functional memory $B$ cells. These data suggest that HIV-associated exhaustion of $\mathrm{B}$ cells may contribute to poor antibody responses against HIV in infected individuals [30]. A subset of ABCB1 CD27-memory CD27 negative-memory B cells lacking FCRL4 has been described in healthy donors and, at increased frequencies, in SLE patients [31].

Subsets of circulating plasma blasts and plasma cells have been identified using surface markers. In steady-state conditions a large fraction of circulating plasma blasts express IgA and the gut-homing molecules CCR10 and beta7-integrin, consistent with a mucosal origin [32]. Newly formed plasma blasts express CD62L, HLADR, and Ki67, while plasma cells displaced from the bone marrow lack these markers [33].

\section{Human marginal zone B cells}

In humans a large fraction of circulating B cells are $\operatorname{IgM}^{\text {hi }}$ $\operatorname{IgD}{ }^{10} \mathrm{CD} 27^{+}$and carry somatically mutated Ig genes [26]. These cells have been initially considered to be $\operatorname{IgM}$ memory B cells, but subsequent studies indicate that they represent a distinct population related to mouse marginal zone $(\mathrm{MZ}) \mathrm{B}$ cells $\left[34^{\bullet \bullet}\right.$ ]. Although they share many properties with their mouse counterpart, such as the response to bacterial polysaccharides, human MZ B cells display striking differences, such as the presence of somatic mutations and the capacity to recirculate. Human MZ B cells develop progressively over the first two years of life explaining the unresponsiveness of infants to polysaccharide vaccines [7]. Furthermore during this time their BCR repertoire undergoes somatic diversification that occurs in the absence of antigen-driven responses. This is clearly demonstrated by the finding that developing MZ B cells have a polyclonal profile of CDR3 spectratyping as opposed to bona fide memory B cells, which display an oligoclonal profile $\left[35^{\bullet \bullet}\right]$. There is relatively little information on the dynamics of $\mathrm{MZ} B$ cell responses. However, in one case analyzed, it was shown that a particular clonotype was detectable at low frequency in the blood before antigenic challenge and was already mutated at this stage. Following vaccination with a polysaccharide vaccine this clone was found expanded in IgM and IgG plasma cells in the spleen and was still detected in blood four weeks later [36]. MZ $\mathrm{B}$ cells are clearly distinct from bona fide IgM memory B cells generated through T-dependent responses that are $\mathrm{IgM}^{\mathrm{hi}} \mathrm{IgD}-\mathrm{CD} 27^{+}$and are found in peripheral blood of normal individuals and at low frequency (1\% of total B cells) and at higher frequency in AID-deficient patients [36].

The above studies outline, for the first time in humans, an antigen-independent mechanism of diversification of the preimmune repertoire, which has been originally described in birds and sheep [37]. This diversification occurs through postrearrangement processes such as gene conversion or somatic hypermutation. There is evidence that this process is $\mathrm{T}$ cell-independent, as shown by the presence of mutated MZ B cells in patients lacking CD40 or CD40L [36] as well as by the analysis of $\mathrm{Rag}^{-1-} \mathrm{gc}^{-1-}$ nude mice reconstituted with human hematopoietic stem cells [38]. In addition it has been recently shown that, unlike naïve B cells, human CD24hi CD38hi transitional B cells respond to $\mathrm{CpG}$ and differentiate into MZ-like B cells [39]. These findings suggest the possibility that BCR diversification might be initiated in transitional B cells by bacterial DNA or other microbial products present at mucosal surfaces. It is striking that humans have selected mutated antibodies for their protection against encapsulated bacteria [40]. A possible reason may be that mutated antibodies produced by human MZ B cells are superior to natural non-mutated polyreactive IgM antibodies [41]. 
Besides their role in antibody production against bacterial polysaccharides $[42,43]$, it is possible that MZ B cells may be involved in other types of immune responses. Indeed, mouse MZ B cells have been shown to play a protective role in host defense against influenza virus [44]. The recent isolation of human monoclonal antibodies neutralizing influenza viruses from a phage library prepared from human MZ B cells would be consistent with this possibility $\left[45^{\circ}\right]$.

\section{Dynamics of memory B cells and plasma cells}

Upon booster immunization, memory B cells expand rapidly and generate a burst of plasma cells that peak on day 7 in peripheral blood. At this time point the number of circulating plasma cells can exceed by 100 fold the baseline level and this increase is accounted for primarily by antigen-specific plasma cells $\left[22,46^{\circ}\right]$. The plasma cell burst coincides with a sharp increase in serum antibodies that reaches plateau levels on day 10, indicating that the vast majority of the plasma cells generated are short-lived. A recent study shows that, in contrast to a widely held belief, the plasma cells generated in response to a new influenza vaccine have higher affinity for the vaccine than for a previously encountered virus, suggesting that in humans the original antigenic sin does not compromise the immediate response to influenza vaccination $\left[46^{\circ}\right]$.

Coincident with the generation of antigen-specific HLA$\mathrm{DR}+$ plasma blasts, a population of HLA-DR - plasma cells appears in the blood in large numbers [33]. The latter cells secrete antibodies of unknown specificity and represent long-lived plasma cells that have been displaced from their niches in the bone marrow and, having lost the capacity to home back, are bound to die [47]. These results are consistent with a novel model, where newly generated and old plasma cells compete for limited numbers of survival niches $\left[2^{\circ}\right]$. A recent mouse study revealed yet another mechanism for turning over of longlived plasma cells, which is mediated by IgG containing immune complexes that trigger apoptosis of bone marrow plasma cells by engaging Fc $\gamma$ RIIb $\left[48^{\circ}\right]$.

A simple method for clonal analysis of memory B cells has been developed using total PBMC stimulated by the TLR7/8 agonist (R848) and IL-2 [49 ${ }^{\circ}$ ]. Using this method it was shown that following a booster immunization the kinetics of antigen-specific B cells was delayed as compared to that of plasma cells, reaching a peak at two weeks and declining over a period of several weeks. The expansion of specific B cells was striking, with peak values reaching up to $50 \%$ of total memory B cells $\left[49^{\circ}\right]$. Multiple parallel assays performed on clonal culture supernatants were used to monitor fine specificity and crossreactivity of the antibodies produced by memory B cells. In particular it was shown that only a small fraction of virus-specific antibodies have neutralizing activity [ $\left.4^{\bullet}\right]$.

\section{Autoreactivity and multispecificity}

Autoreactive B cells which are formed as a consequence of random Ig gene recombination are removed at two checkpoints before maturation into naïve $B$ cells and are virtually absent in MZ B cells [50]. Surprisingly however self-reactive antibodies, including antinuclear antibodies, were frequently expressed by $\mathrm{IgG}+$ memory $\mathrm{B}$ cells in healthy donors [ $\left.51^{\circ \bullet}\right]$. Most of these antibodies were created de novo by somatic hypermutation during the transition between mature naive and IgG+ memory B cells. This finding is consistent with previous reports showing that highly specific antiHIV antibodies can also be polyreactive [52]. It remains to be established whether and to what extent these autoreactive B cells differentiate into plasma cells. It is possible that these autoreactive B cells might be anergic or that other mechanisms exist that prevent their terminal differentiation.

It has long been recognized that a single antibody can bind to multiple unrelated antigens. Multispecificity (often referred to as crossreactivity, degeneracy or promiscuity) offers the mean of expanding the repertoire size providing comprehensive coverage of the antigenic universe. It can be achieved via different mechanisms that range from the rigid recognition of identical residues displayed by different ligands, to a conformational diversity of the antibody allowing binding to structurally distinct ligands, to the differential positioning of ligands in different subsites of the paratope [53]. Recently a therapeutic monoclonal antibody was engineered to express two specificities against HER2 and VEGF [54 $\left.{ }^{\bullet \bullet}\right]$. By screening a randomized library from an HER-2-specific antibody the authors were able to select several variant clones that bound VEGF. While most of these clones had lost reactivity against HER2, others retained such reactivity thus behaving as 'two-in-one' antibody. It is tempting to speculate that a selective process similar to that used to isolate the two-in-one antibody may occur naturally whenever memory $B$ cells are confronted with a new antigen.

\section{B cells and plasma cells as therapeutic targets}

In the last few years B cell and plasma cell depletion has provided new opportunities for treatments of malignancies and autoimmune diseases. The anti-CD20 antibody Rituximab, which targets B cells but not plasma cells, has been approved for the treatment of B cell lymphomas and rheumatoid arthritis and has been used to treat chronic lymphocytic leukemia and autoimmune diseases mediated by autoreactive antibodies, such as systemic lupus erythematosus (SLE) and pemphigus. Therapeutic effects have been observed also in patients with relapsing-remitting multiple sclerosis, providing support for a role of B cells and antibodies in this disease $[55,56]$. 
The mechanism and kinetics of $\mathrm{B}$ cell depletion by Rituximab have been studied in mice expressing human CD20 [57]. The efficiency of B cell depletion was shown to be dependent on a number of factors including the microenvironment, the extent of $\mathrm{B}$ cells recirculation, the expression of $\mathrm{Fc}$ receptors, and complement regulatory proteins such as CD59. Consistent with these animal data, patients that express the high affinity allele of FcyRIIIa (V158) have a better prognostic outcome to Rituximab treatment as compared to patients that express only the low affinity allele (F158) [58,59]. Combinatorial therapies have been considered to increase the effect of anti-CD20 such as fresh plasma or antibodies to CD59. In addition new anti-CD20 antibodies are developed with enhanced capacity to induce ADCC or to fix complement [60].

In autoimmune diseases long-lived plasma cells secreting autoantibodies represent an as yet unmet therapeutic challenge because they are resistant to conventional treatments, such as immunosuppression and anti-CD20 antibodies. However, immunoablation using antithymocyte serum followed by autologous stem cell transplantation has been shown to effectively deplete long-lived plasma cells and induce long-term remission in patients with severe autoimmune diseases [61]. Owing to the high rate of protein synthesis and the limited proteolytic capacity, plasma cells are hypersensitive to proteasome inhibitors such as Bortezomib [62,63]. This drug, which is now approved for the treatment of multiple myeloma, eliminates both short-lived and long-lived autoreactive plasma cells by the activation of the terminal unfolded protein response.

Studies on murine models of B cell depletion provide relevant insights into the dynamics of B cell and plasma cell populations. Two recent studies $[64,65]$ examined plasma cell levels in mice treated with anti-CD20 antibodies and concluded that the long-lived plasma cell pool is maintained despite mature and memory $\mathrm{B}$ cell depletion, at least over a period of 16 weeks. Interestingly, in one of these studies, the authors were able to deplete bone marrow plasma cells by in vivo administration of antibodies to LFA-1 and VLA4. They found that in these conditions memory B cells were required for the repopulation of bone marrow plasma cells [64]. The ability of memory B cells to reconstitute the bone marrow plasma cell pool would be consistent with a contribution of memory B cells to the homeostasis of plasma cells and serum antibody level.

\section{Monoclonal antibodies from memory B cells and plasma cells}

In the last five years several methods have been reported to retrieve monoclonal antibodies from human memory B cells and plasma cells. Much of the impetus for these studies derives from the need to develop antibodies that effectively neutralize human pathogens. Broadly neutra- lizing antibodies could be used not only as therapeutics, but also as tools to design vaccines capable of eliciting a broadly neutralizing response $\left[66^{\circ}\right]$. An improved method of EBV immortalization has been used to isolate from memory B cells of infected patients monoclonal antibodies that potently and broadly neutralize SARS coronavirus [67 ${ }^{\circ}$ ] and $\mathrm{H} 5 \mathrm{~N} 1$ avian influenza virus [68]. An advantage of this method is that the antibodies produced by immortalized B cells can be directly tested using functional assays such as viral neutralization and therefore a precise knowledge of the antigenic target is not required. Another advantage relates to the longevity of memory B cells. This is best exemplified by the isolation from survivors of the 1918 influenza pandemic of monoclonal antibodies that potently neutralize the 1918 H1N1 influenza virus [69].

Using a different approach to analyze the whole spectrum of memory B cells, antigen-binding memory B cells were isolated by cell sorting and the Ig genes cloned by single cell PCR [70. In HIV-1-infected donors, the B cell memory repertoire specific for gp140 was composed of up to 50 independent clones expressing high affinity antibodies of different epitope specificity. Surprisingly, although the donors had broadly neutralizing serum antibodies, none of the antibodies isolated had such a property $\left[70^{\circ}\right]$. This finding raises the possibility that the breadth of neutralization depends from a large number of antibodies, each targeting only a few HIV variants. Alternatively, it is possible that the 'bait' used was not suitable to select $B$ cells of broad specificities or that the repertoire of memory $B$ cells might differ from that of plasma cells which produce serum antibodies.

An alternative source of human monoclonal antibodies is represented by circulating plasma blasts or bone marrow plasma cells. Plasma blasts isolated seven days after boosting are highly enriched for antigen-specific cells and the Ig genes can be rescued by single cell PCR. This approach led to the isolation of antibodies to $\mathrm{Rh}$ blood group antigen, tetanus toxoid, and influenza virus $\left[46^{\bullet}, 71,72\right]$. Considering that plasma cells and memory B cells have different kinetics, it will be interesting to establish whether the antibodies isolated from these sources may have different properties in terms of load of somatic mutations and fine specificity. In the mouse it has been shown that plasma cells emerge from germinal centers after memory B cells and have higher levels of somatic mutations [73].

The novel approaches discussed above complement the well-established method of phage display libraries [74]. This method has been recently used to isolate antibodies capable of neutralizing different subtypes of influenza virus in vitro and in vivo $\left[45^{\bullet}, 75,76^{\circ}\right]$. These antibodies use the same VH1-69 region and inhibit fusion by binding to a conserved site in the stalk region of the 
hemagglutinin with contact residues provided by CDR1 and CDR2 of VH1-69 [77]. At present it is not clear whether such antibodies are made in the course of the immune response to influenza.

In conclusion, the study of the human memory B cell response is continuously providing relevant information that can be rapidly translated in new therapies for autoimmune and infectious diseases.

\section{References and recommended reading}

Papers of particular interest, published within the period of review, have been highlighted as:

- of special interest

$\bullet$ of outstanding interest

1. Rajewsky $\mathrm{K}$ : Clonal selection and learning in the antibody system. Nature 1996, 381:751-758.

2. Radbruch A, Muehlinghaus G, Luger EO, Inamine A, Smith KG,

- Dorner T, Hiepe F: Competence and competition: the challenge of becoming a long-lived plasma cell. Nat Rev Immunol 2006, 6:741-750.

An excellent review that discusses current concepts on the dynamics of long-lived plasma cells in the bone marrow.

3. McHeyzer-Williams LJ, McHeyzer-Williams MG: Antigen-specific memory B cell development. Annu Rev Immunol 2005, 23:487-513.

4. Ruprecht CR, Lanzavecchia A: Toll-like receptor stimulation as a third signal required for activation of human naive B cells. Eur $\mathrm{J}$ Immunol 2006, 36:810-816.

5. Pasare C, Medzhitov R: Control of B-cell responses by Toll-like receptors. Nature 2005, 438:364-368.

6. Gavin AL, Hoebe K, Duong B, Ota T, Martin C, Beutler B, Nemazee D: Adjuvant-enhanced antibody responses in the absence of toll-like receptor signaling. Science 2006 , 314:1936-1938.

7. Kelly DF, Snape MD, Clutterbuck EA, Green S, Snowden C, Diggle L, Yu LM, Borkowski A, Moxon ER, Pollard AJ: CRM197conjugated serogroup $C$ meningococcal capsular polysaccharide, but not the native polysaccharide, induces persistent antigen-specific memory B cells. Blood 2006, 108:2642-2647.

8. Pollard AJ, Perrett KP, Beverley PC: Maintaining protection against invasive bacteria with protein-polysaccharide conjugate vaccines. Nat Rev Immunol 2009, 9:213-220.

9. Obukhanych TV, Nussenzweig MC: T-independent type II immune responses generate memory B cells. J Exp Med 2006 203:305-310.

10. Kroczek RA, Graf D, Brugnoni D, Giliani S, Korthuer U, Ugazio A, Senger G, Mages HW, Villa A, Notarangelo LD: Defective expression of CD40 ligand on T cells causes " $X$-linked immunodeficiency with hyper-IgM (HIGM1)". Immunol Rev 1994, 138:39-59.

11. Revy P, Muto T, Levy $Y$, Geissmann F, Plebani A, Sanal O, Catalan N, Forveille M, Dufourcq-Labelouse R, Gennery A et al.: Activation-induced cytidine deaminase (AID) deficiency causes the autosomal recessive form of the hyper-IgM syndrome (HIGM2). Cell 2000, 102:565-575.

12. Amanna IJ, Carlson NE, Slifka MK: Duration of humoral immunity

- to common viral and vaccine antigens. N Engl J Med 2007 , 357:1903-1915.

A comprehensive study on the duration of serological memory.

13. Tarlinton D, Radbruch A, Hiepe F, Dorner T: Plasma cell differentiation and survival. Curr Opin Immunol 2008, 20:162-169.
14. Belnoue E, Pihlgren M, McGaha TL, Tougne C, Rochat AF, Bossen C, Schneider P, Huard B, Lambert PH, Siegrist CA: APRIL is critical for plasmablast survival in the bone marrow and poorly expressed by early-life bone marrow stromal cells. Blood 2008, 111:2755-2764.

15. Paramithiotis E, Cooper MD: Memory B lymphocytes migrate to bone marrow in humans. Proc Natl Acad Sci U S A 1997, 94:208-212.

16. Mamani-Matsuda M, Cosma A, Weller S, Faili A, Staib C, Garcon L, Hermine O, Beyne-Rauzy O, Fieschi C, Pers JO et al.: The human spleen is a major reservoir for long-lived vaccinia virusspecific memory B cells. Blood 2008, 111:4653-4659.

17. Scholz JL, Crowley JE, Tomayko MM, Steinel N, O'Neill PJ, Quinn WJ 3rd, Goenka R, Miller JP, Cho YH, Long V et al.: BLyS inhibition eliminates primary $B$ cells but leaves natural and acquired humoral immunity intact. Proc Natl Acad Sci U S A 2008, 105:15517-15522.

18. Benson MJ, Dillon SR, Castigli E, Geha RS, Xu S, Lam KP, Noelle RJ: Cutting edge: the dependence of plasma cells and independence of memory B cells on BAFF and APRIL. $\mathrm{J}$ Immunol 2008, 180:3655-3659.

19. Hikida M, Casola S, Takahashi N, Kaji T, Takemori T, Rajewsky K, Kurosaki T: PLC-gamma2 is essential for formation and maintenance of memory B cells. J Exp Med 2009, 206:681-689.

20. Wirths S, Lanzavecchia A: ABCB1 transporter discriminates human resting naive $B$ cells from cycling transitional and memory B cells. Eur J Immunol 2005, 35:3433-3441.

21. Macallan DC, Wallace DL, Zhang $Y$, Ghattas $H$, Asquith B, de Lara C, Worth A, Panayiotakopoulos G, Griffin GE, Tough DF et al. B-cell kinetics in humans: rapid turnover of peripheral blood memory cells. Blood 2005, 105:3633-3640.

22. Bernasconi NL, Traggiai E, Lanzavecchia A: Maintenance of serological memory by polyclonal activation of human memory B cells. Science 2002, 298:2199-2202.

23. Crotty S, Kersh EN, Cannons J, Schwartzberg PL, Ahmed R: SAP is required for generating long-term humoral immunity. Nature 2003, 421:282-287.

24. Ma CS, Nichols KE, Tangye SG: Regulation of cellular and humoral immune responses by the SLAM and SAP families of molecules. Annu Rev Immunol 2007, 25:337-379.

25. Qi H, Cannons JL, Klauschen F, Schwartzberg PL, Germain RN: - SAP-controlled T-B cell interactions underlie germinal centre formation. Nature 2008, 455:764-769.

Using two-photon intravital imaging the authors show that SAP-deficient $\mathrm{T}$ cells are unable to sustain interaction with antigen-specific B cells, explaining the germinal center defect because of SAP deficiency.

26. Klein U, Rajewsky K, Kuppers R: Human immunoglobulin (Ig)M+lgD+ peripheral blood B cells expressing the CD27 cell surface antigen carry somatically mutated variable region genes: CD27 as a general marker for somatically mutated (memory) B cells. J Exp Med 1998, 188:1679-1689.

27. Bernasconi NL, Onai N, Lanzavecchia A: A role for Toll-like receptors in acquired immunity: up-regulation of TLR9 by BCR triggering in naive $B$ cells and constitutive expression in memory B cells. Blood 2003, 101:4500-4504.

28. Ehrhardt GR, Hijikata A, Kitamura H, Ohara O, Wang JY, Cooper MD: Discriminating gene expression profiles of memory B cell subpopulations. J Exp Med 2008, 205:1807-1817.

29. Moir S, Ho J, Malaspina A, Wang W, DiPoto AC, O'Shea MA,

- Roby G, Kottilil S, Arthos J, Proschan MA et al.: Evidence for HIVassociated $B$ cell exhaustion in a dysfunctional memory B cell compartment in HIV-infected viremic individuals. J Exp Med 2008, 205:1797-1805

In this study the authors characterize a population of exhausted B cells present in HIV-viremic patients. These cells are primarily HIV-1-specific and express multiple inhibitory receptors.

30. Moir S, Fauci AS: B cells in HIV infection and disease. Nat ReV Immunol 2009, 9:235-245. 
31. Wei C, Anolik J, Cappione A, Zheng B, Pugh-Bernard A, Brooks J Lee EH, Milner EC, Sanz I: A new population of cells lacking expression of CD27 represents a notable component of the B cell memory compartment in systemic lupus erythematosus. $J$ Immunol 2007, 178:6624-6633.

32. Mei HE, Yoshida T, Sime W, Hiepe F, Thiele K, Manz RA, Radbruch A, Dorner T: Blood-borne human plasma cells in steady state are derived from mucosal immune responses. Blood 2009, 113:2461-2469.

33. Odendahl M, Mei $H$, Hoyer BF, Jacobi AM, Hansen $A$, Muehlinghaus G, Berek C, Hiepe F, Manz R, Radbruch A et al: Generation of migratory antigen-specific plasma blasts and mobilization of resident plasma cells in a secondary immune response. Blood 2005, 105:1614-1621.

34. Weill JC, Weller S, Reynaud CA: Human marginal zone B cells. -• Annu Rev Immunol 2009, 27:267-285.

An excellent review that covers the experiments that led to the discovery of human marginal zone B cells.

35. Weller S, Mamani-Matsuda M, Picard C, Cordier C, Lecoeuche D,

- Gauthier F, Weill JC, Reynaud CA: Somatic diversification in the absence of antigen-driven responses is the hallmark of the IgM+ IgD+ CD27+ B cell repertoire in infants. J Exp Med 2008, 205:1331-1342.

This study shows that human marginal zone B cells diversify their receptors in the absence of antigen.

36. Weller S, Braun MC, Tan BK, Rosenwald A, Cordier C, Conley ME, Plebani A, Kumararatne DS, Bonnet D, Tournilhac $O$ et al.: Human blood IgM "memory" B cells are circulating splenic marginal zone B cells harboring a prediversified immunoglobulin repertoire. Blood 2004, 104:3647-3654.

37. Tarlinton D: Sheepish B cells: evidence for antigenindependent antibody diversification in humans and mice. $J$ Exp Med 2008, 205:1251-1254

38. Scheeren FA, Nagasawa M, Weijer K, Cupedo T, Kirberg J, Legrand $\mathrm{N}$, Spits $\mathrm{H}$ : T cell-independent development and induction of somatic hypermutation in human IgM+lgD+CD27+ B cells. J Exp Med 2008, 205:2033-2042.

39. Capolunghi F, Cascioli S, Giorda E, Rosado MM, Plebani A, Auriti C, Seganti G, Zuntini R, Ferrari S, Cagliuso M et al.: CpG drives human transitional $B$ cells to terminal differentiation and production of natural antibodies. J Immunol 2008, 180:800-808.

40. Mestas J, Hughes CC: Of mice and not men: differences between mouse and human immunology. J Immunol 2004 , 172:2731-2738.

41. Baxendale HE, Johnson M, Stephens RC, Yuste J, Klein N, Brown JS, Goldblatt D: Natural human antibodies to pneumococcus have distinctive molecular characteristics and protect against pneumococcal disease. Clin Exp Immunol 2008 151:51-60.

42. Martin F, Oliver AM, Kearney JF: Marginal zone and B1 B cells unite in the early response against T-independent bloodborne particulate antigens. Immunity 2001, 14:617-629.

43. Kruetzmann $\mathrm{S}$, Rosado MM, Weber $\mathrm{H}$, Germing $U$, Tournilhac $\mathrm{O}$, Peter HH, Berner R, Peters A, Boehm T, Plebani A et al.: Human immunoglobulin M memory B cells controlling Streptococcus pneumoniae infections are generated in the spleen. $J$ Exp Med 2003, 197:939-945.

44. Baumgarth N, Herman OC, Jager GC, Brown LE, Herzenberg LA Chen J: B-1 and B-2 cell-derived immunoglobulin $\mathbf{M}$ antibodies are nonredundant components of the protective response to influenza virus infection. $J$ Exp Med 2000, 192:271-280.

45. Throsby $M$, van den Brink E, Jongeneelen M, Poon LL, Alard P,

- Cornelissen L, Bakker A, Cox F, van Deventer E, Guan Y et al.: Heterosubtypic neutralizing monoclonal antibodies crossprotective against $\mathrm{H} 5 \mathrm{~N} 1$ and $\mathrm{H} 1 \mathrm{~N} 1$ recovered from human IgM+ memory B cells. PLOS ONE 2008, 3:e3942.

Together with Ref. [76"] this study reports the isolation of monoclonal antibodies that neutralizes Influenza A viruses of different subtypes.

46. Wrammert J, Smith K, Miller J, Langley WA, Kokko K, Larsen C, - Zheng NY, Mays I, Garman L, Helms C et al.: Rapid cloning of high-affinity human monoclonal antibodies against influenza virus. Nature 2008, 453:667-671.

By cloning influenza-specific antibodies from single plasma cells isolated after vaccine boosting, the authors provide evidence arguing against an original antigenic sin.

47. Muehlinghaus G, Cigliano L, Huehn S, Peddinghaus $A$ Leyendeckers H, Hauser AE, Hiepe F, Radbruch A, Arce S, Manz RA: Regulation of CXCR3 and CXCR4 expression during terminal differentiation of memory $B$ cells into plasma cells. Blood 2005, 105:3965-3971.

48. Xiang Z, Cutler AJ, Brownlie RJ, Fairfax K, Lawlor KE,

- Severinson E, Walker EU, Manz RA, Tarlinton DM, Smith KG: FcgammaRIlb controls bone marrow plasma cell persistence and apoptosis. Nat Immunol 2007, 8:419-429.

This study shows that FcgammaRllb engagement leads to the deletion of mouse bone marrow plasma cells.

49. Pinna D, Corti D, Jarrossay D, Sallusto F, Lanzavecchia A: Clonal - dissection of the human memory B-cell repertoire following infection or vaccination. Eur J Immunol 2009, 39:1-11.

Using a high-throughput method the authors analyze frequency, kinetics, and fine specificity of human memory B cells.

50. Meffre E, Wardemann H: B-cell tolerance checkpoints in health and autoimmunity. Curr Opin Immunol 2008, 20:632-638.

51. Tiller T, Tsuiji M, Yurasov S, Velinzon K, Nussenzweig MC

-. Wardemann H: Autoreactivity in human IgG+ memory B cells. Immunity 2007, 26:205-213.

This study shows a high frequency of autoreactivity among human IgG memory B cells, which is because of the introduction of somatic mutations.

52. Haynes BF, Fleming J, St Clair EW, Katinger H, Stiegler G, Kunert R, Robinson J, Scearce RM, Plonk K, Staats HF et al.: Cardiolipin polyspecific autoreactivity in two broadly neutralizing HIV-1 antibodies. Science 2005, 308:1906-1908.

53. Sethi DK, Agarwal A, Manivel V, Rao KV, Salunke DM: Differential epitope positioning within the germline antibody paratope enhances promiscuity in the primary immune response. Immunity 2006, 24:429-438.

54. Bostrom J, Yu SF, Kan D, Appleton BA, Lee CV, Billeci K, Man W,

-. Peale F, Ross S, Wiesmann $C$ et al.: Variants of the antibody herceptin that interact with HER2 and VEGF at the antigen binding site. Science 2009, 323:1610-1614.

The authors engineer a second binding site in a specific antibody creating a 'two-in-one antibody'.

55. von Budingen HC, Harrer MD, Kuenzle S, Meier M, Goebels N: Clonally expanded plasma cells in the cerebrospinal fluid of MS patients produce myelin-specific antibodies. Eur J Immunol 2008, 38:2014-2023.

56. Hinson SR, Roemer SF, Lucchinetti CF, Fryer JP, Kryzer TJ, Chamberlain JL, Howe CL, Pittock SJ, Lennon VA: Aquaporin-4binding autoantibodies in patients with neuromyelitis optica impair glutamate transport by down-regulating EAAT2. J Exp Med 2008, 205:2473-2481.

57. Gong Q, Ou Q, Ye S, Lee WP, Cornelius J, DiehI L, Lin WY, Hu Z, $\mathrm{Lu} Y$, Chen $Y$ et al: Importance of cellular microenvironment and circulatory dynamics in B cell immunotherapy. J Immunol 2005, 174:817-826.

58. Weng WK, Levy R: Two immunoglobulin $\mathbf{G}$ fragment $\mathbf{C}$ receptor polymorphisms independently predict response to rituximab in patients with follicular lymphoma. J Clin Oncol 2003, 21:3940-3947.

59. Cartron G, Dacheux L, Salles G, Solal-Celigny P, Bardos P, Colombat $\mathrm{P}$, Watier $\mathrm{H}$ : Therapeutic activity of humanized antiCD20 monoclonal antibody and polymorphism in IgG Fc receptor FcgammaRIIla gene. Blood 2002, 99:754-758.

60. Taylor RP, Lindorfer MA: Immunotherapeutic mechanisms of anti-CD20 monoclonal antibodies. Curr Opin Immunol 2008, 20:444-449.

61. Hoyer BF, Mumtaz IM, Yoshida T, Hiepe F, Radbruch A: How to cope with pathogenic long-lived plasma cells in autoimmune diseases. Ann Rheum Dis 2008, 67(Suppl 3):iii87-89. 
62. Cascio P, Oliva L, Cerruti F, Mariani E, Pasqualetto E, Cenci S, Sitia R: Dampening Ab responses using proteasome inhibitors following in vivo B cell activation. Eur J Immunol 2008, 38:658-667.

63. Neubert K, Meister S, Moser K, Weisel F, Maseda D, Amann K, Wiethe C, Winkler TH, Kalden JR, Manz RA et al.: The proteasome inhibitor bortezomib depletes plasma cells and protects mice with lupus-like disease from nephritis. Nat Med 2008, 14:748-755.

64. DiLillo DJ, Hamaguchi Y, Ueda Y, Yang K, Uchida J, Haas KM, Kelsoe G, Tedder TF: Maintenance of long-lived plasma cells and serological memory despite mature and memory $B$ cell depletion during CD20 immunotherapy in mice. J Immunol 2008, 180:361-371.

65. Ahuja A, Anderson SM, Khalil A, Shlomchik MJ: Maintenance of the plasma cell pool is independent of memory $B$ cells. Proc Natl Acad Sci U S A 2008, 105:4802-4807.

66. Burton DR: Antibodies, viruses and vaccines. Nat Rev Immunol 2002, 2:706-713.

This review discusses, among other things, the use of neutralizing antibodies for vaccine design.

67. Traggiai E, Becker S, Subbarao K, Kolesnikova L, Uematsu Y,

- Gismondo MR, Murphy BR, Rappuoli R, Lanzavecchia A: An efficient method to make human monoclonal antibodies from memory B cells: potent neutralization of SARS coronavirus. Nat Med 2004, 10:871-875.

This study describes a method to make human monoclonal antibodies through immortalization of memory $B$ cells and screening of culture supernatants.

68. Simmons CP, Bernasconi NL, Suguitan AL, Mills K, Ward JM, Chau NV, Hien TT, Sallusto F, Ha do Q, Farrar J et al.: Prophylactic and therapeutic efficacy of human monoclonal antibodies against H5N1 influenza. PLoS Med 2007, 4:e178.

69. Yu X, Tsibane T, McGraw PA, House FS, Keefer CJ, Hicar MD, Tumpey TM, Pappas C, Perrone LA, Martinez O et al.: Neutralizing antibodies derived from the $B$ cells of 1918 influenza pandemic survivors. Nature 2008, 455:532-536.
70. Scheid JF, Mouquet H, Feldhahn N, Seaman MS, Velinzon K,

- Pietzsch J, Ott RG, Anthony RM, Zebroski H, Hurley A et al.: Broad diversity of neutralizing antibodies isolated from memory $B$ cells in HIV-infected individuals. Nature 2009, 458:636-640.

This study describes a method to make human monoclonal antibodies by sorting antigen-binding memory $B$ cells followed by rescue of Ig genes by single cell PCR.

71. Meijer PJ, Andersen PS, Haahr Hansen M, Steinaa L, Jensen A Lantto J, Oleksiewicz MB, Tengbjerg K, Poulsen TR, Coljee VW et al:: Isolation of human antibody repertoires with preservation of the natural heavy and light chain pairing. $J$ Mol Biol 2006, 358:764-772.

72. Poulsen TR, Meijer PJ, Jensen A, Nielsen LS, Andersen PS: Kinetic, affinity, and diversity limits of human polyclonal antibody responses against tetanus toxoid. J Immunol 2007, 179:3841-3850.

73. Takahashi $\mathrm{Y}$, Ohta $\mathrm{H}$, Takemori $\mathrm{T}$ : Fas is required for clonal selection in germinal centers and the subsequent establishment of the memory B cell repertoire. Immunity 2001 , 14:181-192.

74. Williamson RA, Burioni R, Sanna PP, Partridge LJ, Barbas CF 3rd, Burton DR: Human monoclonal antibodies against a plethora of viral pathogens from single combinatorial libraries. Proc Natl Acad Sci U S A 1993, 90:4141-4145.

75. Kashyap AK, Steel J, Oner AF, Dillon MA, Swale RE, Wall KM, Perry KJ, Faynboym A, Ilhan M, Horowitz M et al.: Combinatorial antibody libraries from survivors of the Turkish H5N1 avian influenza outbreak reveal virus neutralization strategies. Proc Natl Acad Sci U S A 2008, 105:5986-5991.

76. Sui J, Hwang WC, Perez S, Wei G, Aird D, Chen LM, Santelli E,

- Stec B, Cadwell G, Ali M et al.: Structural and functional bases for broad-spectrum neutralization of avian and human influenza A viruses. Nat Struct Mol Biol 2009, 16:265-273.

See annotation to Ref. $\left[45^{\circ}\right]$.

77. Ekiert DC, Bhabha G, Elsliger MA, Friesen RH, Jongeneelen M, Throsby M, Goudsmit J, Wilson IA: Antibody recognition of a highly conserved influenza virus epitope. Science 2009, 324:246-251. 